\title{
Are Women Entrepreneurs More Vulnerable Than Their Male Counterparts? - A Content Analysis
}

\author{
Kodisinghe K.A.M.S. ${ }^{1}$, Semasinghe D.M. ${ }^{2}$ \\ ${ }^{l}$ Department of Business Management, \\ University of Wayamba, Sri Lanka \\ menakakodisinghe@gmail.com \\ ${ }^{2}$ Faculty of Commerce and Management Studies, \\ University of Kelaniya, Kelaniya, Sri Lanka \\ semadissanayaka@yahoo.com
}

\begin{abstract}
The objective of this study is to examine the problems faced by women entrepreneurs. Data for the study was mainly based on secondary data and some observations. The basic research method selected for the study was content analysis. For the identification of these issues we have reviewed various research articles and reports published by major journals. Findings of this study reveal that access to finance, social and cultural constrains, lack of specialized education background and advances in technology and role problems are the major problems faced by women entrepreneurs. We recommend that more organizations and networks should be established for the development of women entrepreneurs and to minimise the problems faced by them.
\end{abstract}

Keywords: Women entrepreneurs, Content analysis 


\section{Introduction}

Entrepreneurship and business in general have been male dominated for decades, but this has been changed over the years (Njery \& Bwisa, 2012). Nowadays women empowerment has been increasing so rapidly all over the world and women are starting their own businesses to seek greater control over their personal and professional lives. It can be seen that women entrepreneurship is a growing phenomenon and has had a significant economic impact in all economies (Nieman \& Nieuwenhuizen, 2003). Women entrepreneurs significantly contribute to the success of the economy. They shape and redefine the work place, business networks, financial institutions and culture. A number of initiatives have been designed to motivate women entrepreneurs. Studies show that the experience of women in business is different from those of men. There are profound gender differences in both women experiences of business ownership and the performance of women-owned firms (Carter, Anderson \& Shaw, 2001).

According to Maas and Herrington (2006) as cited in the International Trade Centre- Canada (2004), has experienced a 200\% growth in the number of women entrepreneurs over the last 20 years. Women-owned businesses, as reviewed by statistics in the USA, are the fastest growing sector of new business start-ups, with black women's business forming a larger share of black-owned businesses than white-owned women's businesses (Mattis, 2004). Within the African 
context, women entrepreneurs manage $57 \%$ of small and micro businesses.

Women-owned enterprises have their fair share of challenges and constraints that need to be addressed and specific needs have to be identified to help them perform at par, if not better, than their male counterparts. The challenges that women entrepreneurs face have not been adequately studied and developed. No comprehensive account of studies investigating problems faced by women entrepreneurs has been compiled so far.

According to Nieman and Nieuwenhuizen (2004), regularly a women's role has been that of mother and wife. But this has changed and women are now represented in large numbers in many business sectors. Women entrepreneurs have been the most disadvantaged group because of late they could not pursue a business activity without taking their husband or a male family member along. Although women nowadays are now engaged in the self-employment sector, many people still wonder how a woman can be a successful entrepreneur if she has gender roles to play at home, is or uneducated, unexposed to markets or cut off from financial resources, or just generally discriminated against in a male dominated society (Maas \& Herrington, 2006). Both men and women face difficulties in establishing an enterprise, but women are faced with specific challenges that hinder their business growth and survival. 
The reason why this research study is being undertaken is to investigate the specific challenges faced by women entrepreneurs. The major objective of this article was to identify the critical issues of women entrepreneurship and discuss the various issues regarding to problems of women entrepreneurship. The specific objectives are,

i. Review literature on women entrepreneurship.

ii. Examine challenges of women entrepreneurs.

iii. Recommend solutions to minimise challenges of women entrepreneurs.

The basic research method selected for the study is content analysis. Content analysis is a widely used qualitative research technique. According to Titscher et al. (2000), content analysis is the longest established method of text analysis among the set of empirical methods of social investigation. Content analysis has been defined as a systematic, replicable technique for compressing many words of text into fewer content categories based on explicit rules of coding (Berelson, 1952; GAO, 1996; Krippendorff, 1980; and Weber, 1990). We have used search engines like Google Scholar, Emerald Insight and Ebsco to broadly search for scholarly literature. Articles, theses, books, and abstracts were the sources we have used for this study. Journal articles published in Journal of Business Venturing, Journal of Small Business Management, Entrepreneurship Theory and Practise and International Journal of Business and Commerce were mainly 
used. Hence, the present article is purely based on secondary data collected through literature survey. However, the present authors criticize some of these opinions and make analyses based on the observations and experiences regarding women entrepreneurship.

According to the past literature, problems faced by women entrepreneurs were fragmented. Our contribution of this study is to compile all these significant findings into a single paper. Sequence of this article was first examined the main objectives of the study and the research method with critical analysis of current literature of the scope of the study. Finally, the study was also look for possible solutions to mitigate and minimise these challenges faced by women entrepreneurs.

\section{Literature Review}

In the creation and growth of business ventures, entrepreneurs face a variety of problems, ranging from major financial issues to day-to-day operational issues. Several studies about women entrepreneurs include a number of problems women entrepreneurs encounter that obstruct their success at start-up and growth. Amongst these problems, the lack of access to finance is widely covered in the entrepreneurship literature for both men and women. Other problems highlighted in women's entrepreneurship literature include the lack of managerial, business and technical skills, and lack of access to business networks, 
and combining domestic responsibilities with the management of their ventures.

The OECD (1998, 2000, 2004) and UNIDO (2001) deliberated extensively on the problems women entrepreneurs face in both OECD and non-OECD countries and concluded that the reduction or elimination of these problems will contribute enormously to the success of women entrepreneurs' ventures. It will also enable them to receive the necessary support to equip them to overcome the problems and help to fully develop their potential. The various problems women entrepreneurs encounter, as reported in literature, can be categorized into four major headings, these categories are those also identified by the International Labour Organization (ILO): access to finance; social and cultural constraints; educational and occupational; role problems.

\section{Access to Finance}

Access to finance is frequently investigated in entrepreneurship literature, and is particularly widely regarded as the major obstacle facing women entrepreneurs (Brush 1992; Riding and Swift 1990; Crampton and Mishra 1999; Anna et al. 2000; Hisrich et al. 1997; OECD 1997; Ylinenpaaand Chechurina 2000). These studies reported that the majority of women entrepreneurs face difficulties in obtaining sufficient and affordable capital to start new ventures or expand their business. 
Interestingly, there is considerable anecdotal evidence in literature to suggest that women perceive that they are discriminated against by banks (Fabowale, Orser and Riding 1995; Still 1997; Yago, Ford and Gordon 2000). And, although both male and female entrepreneurs have to contend with a financial environment that has become increasingly demanding, access to financial markets has been regarded as among the most important resources denied women (OECD, 1997). Frequently mentioned problems women face in relation to access to finance includes higher interest rates (Coleman, 2000), huge collateral requirements and ceilings on loans (OECD, 2000). Also, Carter and Kolvereid (1997) noted that among nascent entrepreneurs, men anticipated far greater access to funding through both formal lending sources and from their personal assets than did women.

No research evidence from the extensive review of literature supported the proposition that women suffer gender discrimination. However, previous findings suggest that it does seem that the characteristics of women's business ventures may be less conducive to formal financing (Coleman 1998, 2000). Interestingly, several researchers have found that banks often focus on servicing large- and medium-sized companies to the detriment of small enterprises, in which women are mainly found. For example, Coleman (2000), studying lending practices in the USA, found that women were not discriminated against by gender when seeking bank credit, but as they tend to have smaller firms than men they may be disadvantaged when seeking 
financial help. Despite the growing number of small enterprises and their important economic role, investors have been less inclined to invest in many of these firms because of the perceived cost difficulties of evaluating them. Evidence in literature suggests that banks do not discriminate on the basis of gender but on the size of the company (Coleman 1998, 2000; Verheul and Thurik 2000).

Similarly, findings from a Canadian study conducted by Haines, Orser and Riding (1999) suggested that it is not gender discrimination that disadvantages women, but the fact that they tend to operate smaller, younger and riskier businesses, which makes them less desirable investments. Also, Fabowale et al. (1995) found that women are disadvantaged regarding lending practices not because of overt gender discrimination but due to the structural characteristics of their firms. They found that, generally, women-owned business ventures are smaller, have less capacity, less capital, and unproven track record or character relative to their male counterparts. Brush et al. (2006), also concurring with the above findings, commented that since womenowned businesses are typically smaller, younger and in industries that are less promising, they indirectly face challenges when it comes to bank lending.

In addition, several studies have reported women entrepreneurs' unsatisfactory relationship with financial institutions which has prevented them from approaching them for credit. These studies have 
dealt specifically with banks and funding sources and their behaviour and attitudes towards women entrepreneurs. For example, Nieman and Valla (2005) found that in Eastern and Southern Africa, many women expressed frustration at intimidation from bankers where the bankers placed obstacles for women who sought loans from the banks. This treatment made them feel unwelcome, so they shield away from banks (Nieman and Valla, 2005). In relation to this, Buttner and Rosen (1989) noted that the banking relationship for women may not be satisfying because women entrepreneurs may feel patronized in their interactions with lending officers. They also found that bank managers may associate entrepreneurial characteristics more closely with men than women.

Moreover, it has been suggested that while women's business ventures receive high levels of publicity, women's access to equity capital remains low (Brush et al. 2001, 2006). This is mainly attributed to the fact that with the traditionally male composition of the equity capital community, there are network gaps which may present serious access challenges for women trying to grow their businesses with equity capital (Aldrich 1989). In addition to the problems of access to credit, women have been found to feel less confident about financial affairs. Some Canadian and Australian women were found to lack confidence regarding knowledge of financial options and financial planning skills (Orser and Hogarth-Scott 1995; Still 1997). Also, high performance and growth have been found to correlate with the amount of capital, as 
well as the financial sources that women entrepreneurs can draw upon to facilitate the creation and development of their business ventures (Carter et al. 1996). These financial limitations therefore pose a significant hindrance to the growth and success of women-owned business ventures.

\section{Social and Cultural Constraints}

According to Crampton and Mishra (1999), a major obstacle for women is the presence of constraints imposed upon them by society, the family, and women themselves. They see women still working in a society that often does not accept them as powerful and influential business leaders (Crampton and Mishra 1999). Relationships in our society are structured hierarchically, with women subordinate to men, and having less power, opportunity and access to resources. Relations between men and women in the family, the workplace or in the public sphere reflect how society understands appropriate male and female characteristics and behaviour. Growe and Montgomery (2001) find that society's attitude towards appropriate male and female roles is thus an obstacle that identifies women as not task-oriented enough, too dependent on feedback and evaluations of others, and lacking independence.

Another related barrier is the negative attitudes and stereotypes created by society towards the career woman (Crampton and Mishra 1999). The first stereotype is that women assume more of the physical work 
involved in running a household than men. Secondly, women assume a 'higher level' of household responsibilities. The third, and most discouraging, is that the man's job is considered more important. Although not all women fit this stereotype, Crampton and Mishra (1999) further reported the following stereotypes among the most identifiable barriers to women's advancement, 'women lack career commitment, are not tough enough, don't want to work long or unusual hours, are too emotional, won't relocate, lack quantitative and analytical skills and have trouble making decisions'.

It was found that deep-seated attitudes that have developed over hundreds of years regard women as soft, loving, intuitive, emotional, non-objective, afraid of achievement, poor at quantitative analysis, and unable to make tough decisions. These stereotypes are not applicable to all women and although they may be false, subtly influence women's decisions about careers, roles, behaviours and the futures (Crampton and Mishra 1999). Women sometimes lack the confidence and the skills to overcome these cultural obstacles that are in addition to the problems usually associated with starting a business for any entrepreneur (OECD, 2001). Attempts to stereotype women entrepreneurs may continue because of the lines of business that women establish themselves in. They will continue to be perceived as of little importance, and as a consequence, the advisory system as a whole may not take applications from women entrepreneurs as 
seriously as they do from men. Social and cultural barriers thus affect women's access to entrepreneurial opportunities.

Gender has also been identified in research as playing a major role in creating barriers. The literature provided evidence that females, when compared to males, had frequently encountered greater obstacles to becoming entrepreneurs. Many women entrepreneurs reported some discriminatory attitudes towards them because of their gender. One such barrier identified by Brodsky (1993) is that the presumption of competence which is automatic for males is not so for females. Females must prove themselves and thus they are at a distinct disadvantage in terms of support received for the creation and development of their business.

\section{Lack of Specialized Educational Background and Advances in Technology}

Allen and Truman (1993) revealed that there are differences in the educational levels of entrepreneurs in the more developed economies and those in less developed economies. In the former, the educational level of entrepreneurs is relatively high and the percentage of entrepreneurs without a graduate education is decreasing, whereas entrepreneurs in the latter find themselves with an inadequate education and training base. 
Stevenson (1986) found that women entrepreneurs in developed countries were more likely to have completed high school and university programmes, but they often did not have an educational background in business. Cliff (1998), concurring with this, also identified that women business owners were less likely than men to have business degrees. Fabowale et al. (1995) suggested that this lack of specialisation may raise perceived risk associated with womenowned businesses.

Women entrepreneurs were also found to have difficulties accessing the technological and economic information which is of vital importance in ensuring competitiveness. Women entrepreneurs are unable to access this information due to a lack of time and specialist skills. This lack of technical know-how and poor access to appropriate technologies have also been identified as a major obstacle facing women entrepreneurs in the SMEs sector in most developing countries (Buame, 2000: Steel and Webster, 1990). The impact of technological change on SMEs has revolved around increased capabilities. Technical know-how and the impact of technologies on the way businesses operate help to increase the productivity of women entrepreneurs. For example, the computer communications technological revolution generally improves the flexibility, the capability and the opportunity of women-operated SMEs to form and compete in foreign and domestic markets. Most women entrepreneurs in SMEs in developing countries, however, do not have access to modern technologies. Their technical skills are not up-to-date and even if they are, they mostly lack the 
necessary theoretical background to support their skills since business owners normally have low levels of education.

\section{Role Problems - Balancing Family Responsibility with Business}

Another barrier recurring throughout the literature is the dual role stress that women face. This refers to the concern that women business owners have about balancing work and family commitments. Universally, family responsibility falls primarily on women, and this can occur even when women are involved in entrepreneurship. This may lead to time fragmentation, less chance of entrepreneurial success or general career progression (Brush, 1997). Women experience 'time poverty' in attempting to deal with both commercial and domestic work, leading to greater stress and difficulty (Still 1997).

Chun (1999) found that one of the two greatest problems in starting a business for Canadian women entrepreneurs is the difficulty in balancing business and family responsibilities. Research has indicated that variables such as children showed no statistical relationship with firm performance (Allen and Carter, 1996); this does not mean, however, that domestic responsibilities are not constraining women who wish to create and advance their firms.

This contention was intensified by Crampton and Mishra (1999), who found that in addition to the demands of a career and family, women also experience the additional behavioural expectation placed on them 
by society - the burden of child rearing. Butler (2003) referred to a study by Cole on British women entrepreneurs, which found that many of the respondents considered that there was a 'distinct' conflict between their roles as wives, mothers and businesswomen. The study found that problems arose from the attitudes held by the respondents' families, as well as the business institutions they dealt with. These attitudes led to reduced support and needed extra effort to overcome. Such attitudes tended to undermine the respondents' self-confidence and credibility.

Ylinenpaa and Chechurina (2000) reported that the 'glass ceiling' as a barrier to female aspirations in social production, coupled with a high rate of unemployment, attracts Russian women to the entrepreneurial sector. Starting new, smaller firms serves the double purpose of generating an additional family income and creating an arena for selffulfilment. However, these entrepreneurial ambitions are then combined with the double burden for women of also being the person primarily responsible for domestic responsibilities, including the upbringing of children. Women entrepreneurs, therefore, faced the problem of combining the hard work involved with their businesses with family responsibilities, which they found very stressful and affected the performance and productivity of their businesses. Ylinenpaa and Chechurina (2000) further observed that this 'double burden' that women bear performing both productive and reproductive roles is also a characteristic of women in western economies. Also, a study by Belcourt et al. (1991) concluded that the role of women as 
primary caregivers to children and their perceived responsibility for the household, when added to the role of entrepreneur and businesswoman meant 'role overload', a problem that their male counterparts rarely faced.

\section{Conclusion and Recommendations}

Given the above discussion, it is evident that women entrepreneurs, regardless of the society in which they operate, face several constraints that impede the successful start-up and growth of their entrepreneurial activities. Past research has shown that greater domestic responsibilities decrease women's relative success as small business owners. This is due to the difficulty in managing time between business and personal life. Women entrepreneurs generally lack occupational experience compared to their male counterparts, and also find it very hard to acquire funds for the creation and development of their business ventures. It is therefore expected that Sri Lankan women entrepreneurs also face a host of problems in the start-up and growth of their business ventures. Identification of these problems will allow all the stakeholders to take the necessary steps to develop and incorporate new strategies in institutions, society and government, and most importantly in the women themselves, in order to overcome these problems to enhance their business success.

To offer support and to encourage more women entrepreneurs to engage in business, more organisations should be established for the 
development of women entrepreneurs. These organisations could support them with training and development, financing the business and other support for their entrepreneurial development. Training and development could assist women entrepreneurs to obtain management skills, including skills in preparing business plans, marketing and financial management, which could also bridge the gap in the discrimination in granting credit by the banks. In addition, awareness campaigns should be held so that women entrepreneurs could have knowledge about those organisations, with the result that they could then utilise their support and facilities. Awareness campaigns can also be held on national radio and television for women entrepreneurship training, education and networking with other women entrepreneurs. These initiatives should incorporate the nature and dynamics of women entrepreneurship, the challenges of women in business and the employment of technology for women in business. The training and mentoring programmes will assist the women entrepreneurs in improving the success of their business. To curb the obstacle of pressure of childcare and the family pressures, women entrepreneurs must be taught about how to delegate tasks to employees. More nursery school should be built to minimise this kind of obstacle. The gap in lack of exposure to markets can also be fulfilled with good networking among women entrepreneurs. To ensure that their businesses progress smoothly, established women entrepreneurs should establish networks to help other women entrepreneurs. The government must also help them gain access to international markets. 


\section{References}

Aldrich, H. (1989). 'Networking among Women Entrepreneurs', in Hagan, O., Rivchun, C., \& Sexton, D. (eds), Women-Owned Businesses, Praeger, New York.

Allen, K., \& Carter, N. (1996). 'Women Entrepreneurs: Profile Difference across High and Low-Performing Adolescent Firms', in Reynolds, P., Birly, S., Davidsson, P., Butler, J., Gartner, W., Bygrave, W., \& Mc Dougall, P. (eds), Frontiers of Entrepreneurship Research, Babson College, Wellesley, Massachusetts.

Allen, S., \& Trumen, C. (1993). Women in Business: Perspectives on Women Entrepreneurs, Routledge Press, London.

Anna, A., Chandler, G., Jansen, E., \& Mero, N. (2000). 'Women Business Owners in Traditional and Non-Traditional Industries', Journal of Business Venturing, vol. 15, no. 3, pp. 279-303.

Belcourt, M., Burke, R., \& Lee-Gosselin, H. (1991). 'Women Business Owners in Canada', Canadian Advisory Council on the Status of Women, Ottawa.

Brodsky, M. (1993). 'Successful Female Corporate Managers and Entrepreneurs: Similarities and Differences', Group and Organization Management, vol.18, no.3, pp. 366-78.

Brush, C.G. (1992). 'Research on Women Business Owners: Past trends, a new perspective, and future directions', Entrepreneurship Theory and Practice, vol.16, no.4, pp.5- 30.

Brush, C.G., Carter, N., Gatewood, E., Greene, P., \& Hart, M. (2001). 'The Diana Project: Women Business Owners and Equity Capital: The Myths Dispelled', Report 1, Ewing Marion Kauffman Foundation, Kansas City, Missouri. 
Brush, C.G., Carter, N., Gatewood, E., Greene, P., \& Hart, M. (2006). Growth-Oriented Women Entrepreneurs and their Businesses: A Global Research Perspective Edward Elgar Publishing, Cheltenham.

Buame, S. (2000). Advanced Entrepreneurship: Enterprise Culture, Venture Creation, Promotion \& Management of SMEs in Ghana, University of Ghana Press, Accra.

Buttner, E.H., \& Rosen, B. (1989). 'Funding new Business Ventures: Are Decision makers biased against Women Entrepreneurs?' Journal of Business Venturing, vol. 4, no. 4, pp. 249-61.

Carter, N.M., \& Kolvereid, L. (1997). 'Women Starting New Businesses: The Experience in Norway and the United States', Paper presented at the OECD Conference: Women Entrepreneurs in Small and Medium Enterprises, Paris.

Carter, N.M., Gartner, W.B., \& Reynolds, P.D., (1996). 'Exploring Startup event sequences', Journal of Business Venturing, vol.11, pp.151-166.

Carter, S., Anderson, S., \& Shaw, E. (2001). 'Women's Business Ownership: A Review of the Academic, Popular and Internet Literature', Report to the Small Business Service, University of Strathclyde, Glassgow.

Chun, B.J. (1999). 'Women Entrepreneurs in SMEs in the Asia-Pacific Economic Cooperation (APEC) Region', APEC 1997, Singapore.

Cliff, J.E. (1998). 'Does one Size Fit All? Exploring the Relationship between Attitudes towards, Growth, Gender, and Business and Size' Journal of Business Venturing, vol. 13, no. 6, pp. 523-542. 
Coleman, S. (1988). Access to Capital: A Comparison of Men and Women-Owned Small Businesses (Frontiers of Entrepreneurship Research, 1998), Babson College, Babson Park, Massachusetts.

Coleman, S. (2000). 'Access to Capital and Terms of Credit: A Comparison of Men and Women-Owned Small Business', Journal of Small Business Management, vol. 38, no. 3, pp. 37-52.

Crampton, S., \& Mishra, J.M. (1999). 'Women in management', Public Personnel Management, vol. 28, no. 1, pp.1-13.

Fabowale, L., Orser, B., \& Riding, A. (1995). Gender, structural factors, and credit terms between Canadian small businesses and financial institutions', Entrepreneurship Theory and Practice, vol. 9, no. 4, pp.41-65.

Growe, R., \& Montgomery, P. (2001). 'Women and the leadership paradigm: Bridging the gender gap': http://www.national forum.com/I 2growe.htm, viewed 15th March 2015.

Hisrich R.D., \& Brush, C. (1983). 'The Woman Entrepreneur: Management Skills and Business Problems', Journal of Small Business Management vol.17, May, pp. 30- 37.

Maas, G., \& Herrington, M. (2006). Global Entrepreneurship Monitor: South African Executive Report, Graduate School of Business, Cape Town: University of Cape Town.

Millman, A. (1997). 'The Role of Networks', Proceedings of OECD Conference on Women entrepreneurs in small and medium enterprises: A major force in innovation and job creation' 16-18 April 1997, Paris.

Nieman, G., \& Valla, S. (2005). 'Barriers Facing Female Entrepreneurs; A Study in Gauteng Province, South Africa', Proceedings of 2 nd Entrepreneurship Research Exchange Conference, Melbourne. 
Nieman, G.H., \& Nieuwenhuizen, C. (2003). Entrepreneurship: A South African Perspective, $2^{\text {nd }}$ Ed., Pretoria, Van Schaik.

Njery, P.W., \& Bwisa, H.M. (2012). Gender based entrepreneurial mind set and their influence on performance of small and medium manufacturing firms, International Journal of Business and Commerce, Vol. 1, No. 9: May 2012 (182-198)

Organization for Economic Co-operation and Development (OECD), (1998). 'Fostering Entrepreneurship', Proceedings of OECD Conference on Jobs Strategy, Paris

Organization for Economic Co-operation and Development (OECD), (2000). 'Women Entrepreneurs in SMEs: Realizing the Benefits of Globalization and the Knowledge Based Economy', Proceedings of OECD Conference, Paris.

Organization for Economic Co-operation and Development (OECD), (2004). 'Promoting Entrepreneurship and Innovative SMEs in a Global Economy: Towards a more Responsive and Inclusive Globalization' Proceedings of OECD Conference on Women's Entrepreneurship: Issues and Policies', OECD, Istanbul, Turkey.

Orser, B.J., \& Hogarth-Scott, S. (1995). 'Growth, Gender and Managerial Capacity: An Exploratory Study of Canadian Small and Medium Enterprises'. ISBA. Available http://strategis.ic.gc.ca/SSgf/mi0397f.html, viewed 10 February 2015.

Riding, A., \& Swift, C. (1990). 'Women Business Owners and Terms of Credit: Some Empirical Findings of the Canadian Experience', Journal of Business Venturing, vol. 5, no. 5, pp. 327-340. 
Steel, W.F., \& Webster, L. (1990). 'Ghana's Small Enterprise Sector: Survey of Adjustment Response and Constraints' Industry Series Paper 41, World Bank, Industry and Energy Dept. Washington D.C.

Stevenson, L.A. (1986). 'Against all odds: The Entrepreneurship of Women', Journal of Small Business Management, vol. 24, no.4, pp. 30-36.

Still, L. (1997). Glass Ceilings and Sticky Floors: Barriers to the Careers of Women in the Australian Finance Industry, Canberra, Australia: A report prepared for the Human Rights and Equal Opportunity Commission and Westpac Bank, Australia.

United Nations Industrial Development Organisation (UNIDO), (2001). 'Women Entrepreneurship Development in Selected African Countries', Working Paper No. 7, United Nations Industrial Development Organisation, Vienna.

Verheul, I., \& Thurik, A.R. (2000). 'Start-up Capital: Does Gender Matter?' Small Business Economics vol.16, pp.329-345.

Yago, G., Ford, R., \& Gordon, J (2000). Economic Prosperity, Women and Access to Credit, Best Practices in the Financial Markets, Milken Institute and National Women's Business Council, Santa Monica, California.

Ylinenpaa, H., \& Chechurina, M. (2000). 'Perceptions of Female Entrepreneurship in Russia' Paper presented at EFMD 30th small Business Seminar in Ghent, Belgium, September 2000, http://www.ies.luth.se/og/AR2000 45.pdf, viewed 24th January 2015. 